DOI: 10.20472/AHC.2019.005.008

\author{
TATJANA ŠEPIĆ \\ The Polytechnic of Rijeka, Croatia
}

\title{
READING EMILY BRONTË'S WUTHERING HEIGHTS AND GEORGE SAND'S MAUPRAT AS MUSICAL NOVELS
}

\begin{abstract}
:
Emily Brontë (1818-1848) wrote a single novel and some two hundred poems. George Sand (1804-1876) was a prolific author and one at home in diverse genres, from fiction, autobiographical and political texts, to theatre pieces. These two women writers also had different family backgrounds and different personalities.

In spite of the obvious differences, they had some common interests, such as the love of nature and music, vivid and creative imagination. Passionate and curious readers since their earliest childhood, they read avidly whatever was available to them without any restrictions, an experience that shaped their literary tastes and inspired their first attempts at writing at an early age.

Inclined to daydreaming and making up stories, as a way of coping with traumatic losses they experienced in their childhood, little Emily and Aurore (future George Sand) started creating their imaginary worlds that would accompany them for the rest of their lives. Brontë's poetry and her lost Gondal saga, and Sand's oral and "silent" novel of Corambé were the sources of inspiration and poetic space from which their mature works Wuthering Heights and Mauprat would be created.

Besides numerous similarities between these two novels in the plot, structure, characters and semantically coded space and landscape, both literary texts bear affinities to another form of art, namely, to music. Emily Brontë's and George Sand's great love of music is mirrored in the structure and texture of their narratives at both macro and micro-level: from the polyphonic structure and the four movement form of a symphony or a sonata, together with multiple narrative voices, the variations and development of primary and secondary themes (of love-romantic, transcendent, parental, sibling, and the denial of love, of violence, the dichotomy between nature and culture), the repetition of motifs that appear as antithetical polarities in dialogue (of [non-identical] doubles and the problem of fragmented identity, of freedom and confinement, of reason and madness, life and death), the elements of folklore and the supernatural, lyrical and dramatic passages to poetic imagery, language and rhythm of their prose. Wuthering Heights and Mauprat can therefore be read as novels written by poetesses-musicians who crossed medial boundaries and created musical novels by borrowing structures, techniques and impressions typical of a classical piece of music. Like a musical score, Wuthering Heights and Mauprat with their complex structure and nature exist as a unique piece of art, offering at the same time different possibilities of interpretation.
\end{abstract}

\section{Keywords:}

Wuthering Heights, Mauprat, musical novel, poetesses-musicians, interpretation 


\section{Introduction}

In the context of the 19th century French and English literature, the names of George Sand (1804-1876) and Emily Brontë (1818-1848) occupy a particular place. For more than 150 years their literary output together with their exceptional personalities have intrigued common readers and literary critics alike, creating a myth around them which continues to develop today. Their lives have also inspired numerous (fictionalized) biographies, and together with their novels (in particular E. Brontë's Wuthering Heights) have also spawned different stage, film and televised adaptations, even versions in comics, opera and musical.

In spite of the shift in the academic criticism in the last few decades, in particular owing to some feminist readings of George Sand's novels, in popular imagery the writer's name was, and still is, synonymous with a scandalous woman who wore trousers, smoked cigars, with the authoress of a large and diverse oeuvre of no great literary value.

One novel, a book of poetry, nine devoirs written in French, a few diary papers, two short letters, and finally two portraits painted by her brother Branwell is all we have of Emily Brontë. Ever since her death, readers and critics have been (re)reading and (re)interpreting her scarce literary output in search of the missing fragments of a mosaic representing Emily Brontë woman, writer, poet, artist. This continuous strife to understand and to penetrate into her enigmatic personality and fill in the void she left behind her, resulted in creating a romantic image of Emily as a mystic, solitary genius, the victim of her family and society, a wild girl who freely wanders the moors, absorbing the images and sounds of nature only to translate them into words.

At first sight, these two women artists could not be more different. George Sand, whose real name was Amantine-Aurore-Lucile Dupin de Francueil, baroness Dudevant, was born and brought up in the aristocratic style and milieu. Although Sand's mother had working class origins, her grandmother on her father's side, was a descendant, through an illegitimate line, of FrédéricAugustus II, King of Poland. This social and cultural métissage would profoundly mark George Sand's life and consequently her work.

Emily Brontë was born as the fifth of six children of Maria Branwell, from a prominent and prosperous Cornish merchant family, and Reverend Patrick Brontë, the eldest of ten children born to a poor Irish tenant farmer. In 1820, when Emily was two years old, the family moved to Haworth, a village in West Yorkshire, where Patrick Brontë was given the post of the perpetual curate. In spite of his rise in the church hierarchy, the family lived in straitened circumstances since he had no other source of income other than his salary.

Unlike Emily, who is remembered as an extremely reserved and introverted child and later on young woman, during her lifetime George Sand had developed numerous friendships, exchanged thousands of letters with her closest family, friends, fellow writers, artists, musicians, thinkers, 
critics, readers and acquaintances. ${ }^{1}$ She negotiated with her editors and publishers on equal terms as any of her male colleagues. She also expressed her political and feminist ideas freely and incorporated them into her (non)fictional works. The "red baroness", as she is sometimes called, witnessed or even took an active part in some of the most dramatic historical events that shook Paris and France in the long nineteenth century.

\section{Becoming a writer and the role of music}

Although Emily and Aurore had essentially different characters and came from different family backgrounds, they shared some common interests such as the love of nature and the passion for arts, in particular music. They were also curious and avid readers before they became (young) writers. Apart from two brief periods that Emily spent at different boarding schools, and Aurore's two years in a convent in Paris, neither of them had a proper formal education, which was quite common for girls at that time.

Aurore-George received her first lessons from her mother Sophie-Victoire, who taught her to read and write. Sophie-Victoire also read her stories, fairy tales, or sang songs and lullabies. Little Aurore was enchanted and soothed by her mother's voice that often lulled her into a kind of slumber, blurring the difference between the real world and her imagination.

The inclination towards daydreaming had grown even more intense over the years. For the little girl and later on the teenager, it became a way to cope with the traumatic losses she had experienced very early in her life. The deaths of her baby brother and father when she was only four years old, and having been abandoned by her mother later on, caused Aurore deep anguish and suffering she would never be able to recover from. When she was about ten or eleven, her imagination created Corambé, a "phantom" that came to her first in a dream. A friend, a sister, male and female at the same time, a mixture of pagan mythology and biblical figures, an ideal creature who comforted her, who gave and received unconditional love her mother and grandmother seemed incapable of. Corambé was a private god of Aurore's childhood world, the title and the main character of her oral, polymorphic, infinite novel. She herself recognized it as a source of inspiration and poetic space from which her mature works would be created (Sand, 1991, p. 925).

At Nohant, her grandmother's manor house in Berry, Aurore enjoyed spending time outdoors, in close contact with nature and the local peasantry, listening to their songs, stories, and legends in the Berrishon dialect (Sand, 1991, p. 620). Before being sent to the convent, she received some kind of formal education by her father's tutor Deschartres, who taught Aurore French grammar and literature, Latin, maths, history and geography. Now, after two years passed in the The Couvent des Augustines Anglaises, she was back at Nohant. She started reading avidly from her

\footnotetext{
${ }^{1}$ Georges Lubin collected and edited nearly 20000 out of 45000 Sand's letters. The author's correspondence was published in 26 volumes by Gallimard, Paris in the period between 1966-1991.
} 
grandmother's library, (Romantic) poets such as Byron, Shakespeare, Milton, Dante, Tasso, the works by Scott, Chateaubriand, Rousseau, together with philosophers, moralists, the classics, "all without order and method, as they fell to my hand" (Sand, 1991, p. 763).

But as much as Aurore "savored with delight" (Sand, 1991, p. 763) poets, writers, thinkers, she had one more passion that always superseded all other forms of artistic expression, and that passion was music. The theme of music runs through her autobiography from the very beginning. Aurore-George's first musical memories are linked with the image of her mother, whose ravishing, light and pure voice she associated in her imagination with the birds singing. Aurore believed she came by this gift through her mother, who was a great artist even though she did not know the notes. When describing her musical memories, it is the voice, rather than instrumental music that Aurore is particularly enchanted with. She herself finds it easier to express her emotions by singing than by using words (Sand, 1991, pp. 599, 601).

Aurore's grandmother, who was an accomplished musician herself, sang to Aurore in her cracked but still beautiful voice airs of eighteenth-century music, in particular the airs of Italian masters and some old opera scores. The old Mme Dupin wanted her granddaughter to receive a proper aristocratic upbringing and that included music lessons as well. Aurore therefore learned to play the piano-forte, the harp and the guitar, and she was taught the principles of harmony.

If her mother's voice spurred and fed her imagination, her grandmother's music "simple and grand in conception, calm and classical in form" introduced her into the world of music that she "admirably understood and felt" (Sand, 1991, p. 482).

Still, in spite of her enormous enthusiasm for music, and her musical family background, the lack of proper teachers caused her to lose interest in the subject convinced she had no talent for it. Now, looking back at her childhood years, she regrets not having been able to develop her gift for music because after all she "was a born musician and could feel and interpret what others created and produced" (Sand, 1991, p. 626). Her words written in a letter to Pauline Viardot speak how strongly she felt about it:

Oh, how much I would like to be fifteen sometimes (...) I would dedicate myself to music with my whole body and soul, and through that language, the most perfect of all languages, I would like to express my feelings and emotions. I would like to create words and music at the same time. (Mallet, 1995, p. 297)

Even though she realizes it is only a dream, music is nevertheless going to be present in her life and work in many other different ways. Not only is her autobiographical identity played out in the space between "the musical self and the writer self" (Bara, 2006, pp. 143-144), but many of her fictional and non-fictional works will be in some way connected with music, either through their structure or rhythm, characters of musicians, commentaries and reflections on particular pieces of music, composers or on music in general as "a universal language", "the most beautiful of all arts" (Mallet, 1995, p. 288). In some of her letters Sand is a music critic as well. In spite of the lack of theoretical knowledge, the style and the content of these musical writings, where Sand formulates 
her judgements and musical theories, are so original that Francine Mallet calls her "a creative critic" (1995, p. 290).

Thérèse Marix-Spire in her book Les Romantiques et la Musique. Le Cas George Sand, 18041838 describes musical elements in Sand's works written until 1838. She also gives numerous details on the writer's musical education and friendships. Already, at the beginning of her literary career in Paris, G. Sand met nearly all great musical figures of her time, Liszt, Meyerbeer, Marie Malibran, Pauline Viardot, Berlioz, and Chopin (1954).

David A. Powell in his book While the Music Lasts: The Representation of Music in the Works of George Sand on the example of some Sand's novels, namely Le Contrebandier, Les Sept cordes de la lyre, Consuelo, La Comtesse de Rudolstadt, Les maîtres sonneurs, that Marix-Spire did not deal with in her critical book, studied the relationship and the influence of music on these Sand's novels, trying to answer the questions such as the possibility of translating one form of art into another, i.e. of transposing a musical structure into a literary text and the results it had produced on the novel as a genre. He also discussed the role of a musical instrument and its relation to a fictional character, the way Sand used music to create a particular atmosphere where music symbolizes both space and time, as well as the importance of music history and its impact on a literary text (2001).

The fluency, the melodic and lyrical qualities of G. Sand's sentences, vibrato tones, lively strokes, fast, pulsating rhythm, the alteration of appassionato passages with moderato cantabile tempo characterize many of her works, from novels, autobiographical texts to letters. We can therefore say that she succeeded in fulfilling her dream of expressing herself through music and words at the same time, thus giving her texts a new and different dimension.

As opposed to the common image of the Brontë children growing up in a remote village of Haworth in the midst of Yorkshire moors, their childhood reality was substantially different. It is true that they kept much to themselves and rarely searched for company outside their narrow family circle.

Apart from a few relatively short periods spent at boarding schools, the Brontë children were mostly educated at home by their father Patrick Brontë, who was also a talented poet for whom writing was "a consuming passion" (Barker, 2007, p. 25), a compulsion that he later on recognized in his children and encouraged it. His way of teaching was quite unorthodox, reflecting his own intellectual interests and passions. The children gained a broad knowledge in history, geography, grammar, and of course, literature and the Bible. Intellectual independence and the unconventional way of thinking were the qualities he tried to develop in his children. They were allowed to read without any restrictions or censorship from their household library, and the public libraries of Haworth and the nearby city of Keighley. Their miscellany of reading included books of every kind, from the Bible and the Prayer Book, the Romantic poets (even the "dangerous" ones like Byron and Shelley, [Barker, 2007, pp. 23-24]), Shakespeare, Milton, Macpherson's Ossian, the Arabian Nights and Aesop's Fables to Gothic novels and the novels written by Sir Walter 
Scott, together with newspapers and periodicals such as Blackwood's and Fraser's Magazine. From avid readers they became young writers. In their virtual words of Angria and Gondal, historical and actual political and social events and persons interweaved with fictional characters and places; reality and fiction mixed in the same way as they did in their everyday life at the Parsonage. The abundant juvenilia was also a source of inspiration and poetic space from which later on their published poetry and fiction would be created. What is left of the Gondal saga, developed by two younger sisters, are poems written by Emily. Some scholars ${ }^{2}$ have shown the way these poems are connected with Emily Brontë's Wuthering Heights, sharing with the novel not only some characters, rhythm, imagery but also a whole "landscape of feeling" (Donoghue, 1970, p. 159).

The Brontë children, in particular the girls, received the kind of education that would prepare them to become self-supporting as teachers or governesses one day, since their father had no means to provide for them financially. This is why Patrick Brontë, in spite of his limited income, decided to arrange drawing and music lessons for his children.

Music played an important part in the family life at the Parsonage, just as it did for the middle and upper classes in general in the first half of the nineteenth century (Hennessy, 2018, p. 24). Of all the Brontë children, Emily seems to have been the most gifted musician. Her talent and inclinations towards music, in particular the piano playing, far exceeded parlour performances where young (Victorian) women were commonly expected and encouraged to display their musical achievements. Even before she went to Brussels, Emily together with her father and her siblings attended concerts in Haworth and neighbouring towns. Although cultural life in Haworth could not be compared with those in big cities, it still had "surprisingly, a venerable musical tradition" (Barker, 2007, p. 21). In 1842, Emily with her sister Charlotte left for Brussels. Their stay at the Pensionnat Heger was supposed to help them improve their knowledge of foreign languages and other subjects necessary in order to set up a school of their own one day. Emily's talent was immediately recognized by $\mathrm{M}$. Heger, who not only allowed her to teach music to younger pupils, but also arranged piano lessons for her with $M$. Chapelle from the Royal Conservatory "the finest teacher in Belgium" (Hennessy, 2018, p. 48).

At the time the Brontë sisters were in Brussels, concerts were presented regularly and some of the performances included the symphonies of Emily's favourite composer Beethoven (Hennessy, 2018 , pp. 41-56, Davies, 2007, p. 41). Berlioz visited the city in that period and he conducted two concerts featuring his works, one of them being Symphonie Fantastique (Hennessy, 2018, pp. 5053). Emily probably attended some of these concerts, although there is no evidence of that. The fact is that there were huge differences between what the cultural life in Brussels offered compared to the narrow world of Haworth. Her staying in Belgium gave Emily an opportunity to

2 See for example M. Visick. (1967). The Genesis of "Wuthering Heights". 2nd ed. London: Hong Kong University. 
get in touch with European culture, in particular (German) literature and music that profoundly influenced her and had lasting impact on her work.

During those months in Brussels her taste in music had also changed. After her return to Haworth the music she purchased and played, in particular The Musical Library (the anthology that included eight volumes of vocal and instrumental music), clearly shows that there was a shift in quality - "emotional, artistic, spiritual" - compared to the quality of music she had played in the 1830s (Wallace, 1986, pp. 154-155, 158-159). Unlike G. Sand, who very often expressed her preference for vocal music, Emily was more interested in playing rather than singing. Her music book containing excerpts from Beethoven, Gluck, Bach, Haydn, Handel, Dussek, Mozart, among others, is heavily marked, indicating that she seriously studied and played these composers (Davies, 2007, pp. 42-43).

A closer look at the annotated sheet music preserved at the Parsonage shows Emily's consistent preference for Beethoven and his symphonies (Wallace, 1986, p. 160). In the dualism that characterizes the music of this great composer, Emily found affinities with her experience of nature and art. Beethoven's artistic soul, just like Emily's, could not bear any kind of restriction that would hinder his imagination, and he found in nature, his most delightful refuge, calm and comfort as he was struggling with his progressing deafness. Apart from their "intrinsic need for communion with Nature" (Hennessy, 2018, p. 59) and rebellious, obstinate personalities defined as "a force of nature" (Hennessy, 2018, p. 59, Davies, 2007), in the past critics have often used similar vehement words to describe their creative output (Hennessy, 2018, pp. 63-64). Beethoven's music, just like Emily Brontë's novel, "invokes the most intense emotions, [but not] at the expense of classical principles of structure" (Hennessy, 2018, pp. 59-60).

The time spent abroad decisively expanded Emily's knowledge and understanding of music. It also helped develop her sense of music as language and language as music. The synthetic character of Romanticism that is reflected in the works of multi-talented artists such as, for example, E.T. Hoffmann or William Blake, explored the relationship between music, literature and painting. Variations and developments of themes, the repetition of motifs, a slow crescendo that reaches the climax into the grand finale and ending in bright and optimistic tones, the elements of folklore and the fantastic, describing nature in lyrical tones, passionate effusions of emotions are words that could be used to speak both of a piece of music and of a literary work.

It is therefore not surprising, having in mind the passion and the talent for music both George Sand and Emily Brontë demonstrated, that some scholars, as it has already been briefly touched upon, have tried to establish the link between their literary works and music, i.e. to read some G. Sand's works and Emily Brontë's Wuthering Heights as novels written by poetesses-musicians. 


\section{Mauprat and Wuthering Heights as musical novels}

In popular imagery both Wuthering Heights and Mauprat are read as a supreme celebration of an idealized, magnified, but also obsessive love that lasts beyond death. In this paper we propose to analyse similarities these two novels share in the plot, structure, characters, semantically coded space and landscape, as well as in the use of imagery, using categories and terms by which a work of prose fiction and a piece of (instrumental) music can be compared.

Although critics in their studies of the relationship between Sand's works and music do not mention Mauprat, it seems legitimate to propose such an interpretation, in particular if we have in mind F. Mallet's words that after Lélia, many of Sand's novels can be called symphonies because of their poetic quality and structure (Mallet, 1995, p. 299). D. A. Powel suggests that any analysis of Sand's works should consider the link between words and music to the extent and in the way each particular prose work requires (Powel, 2001).

\section{The structure of a symphony or sonata}

Analysing the structure of Wuthering Heights critics have shown that when Emily Brontë was writing her novel, she "thought musically" (Davies, 2007, p. 44). "The compositional logic" (Davies, 1994, p. 52) and "the passion and fury" (Wallace, 1986, p. 13) of Beethoven's musical language were transposed into the writer's poetic language and the medium of the novel.

Both Wuthering Heights and Mauprat possess the architectonic structure of the classical symphony or sonata form enriched with subjective and emotional elements characteristic of the Romantic age. The novels are structured on the principle of dualism, of antithesis in the constant dialogue that manages to achieve a "tense equilibrium" (Wallace, 1986, p. 5). In spite of strong emotions of love, passion, fury, hatred, revenge and tumultuous events, all typically Romantic features, the form of the novel remains stable and symmetrical. This tension between form and content that characterizes some of Beethoven's sonatas as well as G. Sand's Mauprat and E. Brontë's Wuthering Heights is what Robert K. Wallace calls "Romantic equilibrium" (1986, p. 13).

The coexistence of opposites and the dual nature of Wuthering Heights is reflected in the novel's original two-volume structure and in the story framed by two major narrators, male and female, intertwining the destinies of two generations of the Earnshaw and the Linton families, in two opposing houses, Thrushcross Grange and Wuthering Heights. There is a repetition, revising and mirroring of the relationships between characters and between generations. The novel has two endings, the latter one itself being double, i.e. the marriage between Cathy and Hareton and the ambivalent destiny of Catherine and Heathcliff, who sleep "in that quite earth" (Brontë, 1983, p. 367), or perhaps as ghosts still walk the moors, as some local people believe.

In Sand's Mauprat there are two of everything as in Brontë's novel. Mauprat is the name of two main characters, Bernard and Edmée, of the two branches of the Mauprat family, the senior branch known by the name Cut-throat (Coupe-Jarret) and the junior one nicknamed Headbreaker (Casse-tête), living on two opposing estates of la Roche-Mauprat and Sainte-Sévère. There are 
also two major narrators, (fe)male and male, and characters that in certain moments we experience as doubles or pairs of similar or opposing characteristics. The story of the novel is organized around two episodes of hunting, one at the beginning of the novel that ends up in Edmée being taken captive by the Coupe-Jarret Mauprats and her escape with Bernard from la Roche-Mauprat. The second scene of hunting occurs towards the end of the book when the heroine gets wounded. The same motif of hunting is repeated two more times, in the central part of the novel in the context of the American War of Independence, in which the main hero took part, and in a comic scene with Marcasse, the mole-catcher.

As in the classical sonata form, where the major themes are introduced in the first section called the exposition, the first three chapters of Wuthering Heights represent not only the novel's "overture", but its "microcosm" as well (Crehan in Goodridge, 1971, pp. 15-16), since they contain all the important elements of the story we are about to read: Heathcliff's agony, Cathy's ill-fated destiny, a powerful and destructive need of Catherine's ghost to enter her room after twenty years of wandering on the moor and Hareton's ambiguous position as a servant and the future rightful heir/owner of Wuthering Heights. In the repetition of names, the third chapter itself presents the whole plot and theme of the novel. The window-ledge with the scribbled names of the "swarming Catherines" (Brontë, 1983, p. 61) encode and recapitulate the main theme of the story and the destinies of both the late Catherine and her daughter Cathy. Comparing the opening bars of Beethoven's Sonata Pathétique and the opening pages of Brontë's novel, Wallace finds they both have a "condensed and concentrated" texture and that at the same time they express vehement emotions producing shock, as well as sharp conflict and contrast (1986, pp. 35, 38).

The dramatic and lyrical tones, the contrasting tune and the themes presented in the introductory chapters will be developed in the course of the novel, moving forward and backwards in time, between the Heights and the Grange. The last three chapters mirror the first three, restoring not only the narrative to Lockwood, but also (at least apparently) the calm after the stormy opening chapters, resolving the secrets and tensions announced at the beginning of the novel.

This outer frame encloses the tragic, "wuthering" story of Catherine and Heathcliff, and the more conventional love story between Cathy and Hareton, whose destiny in many ways repeats the story of the first generation, only this time "retelling it in the right way" (Gilbert and Gubar, 1984, p. 301). Or, we can say that it represents the repetition with variations on the first theme that ends up with Catherine's death and the birth of her daughter. The Cathy-Linton-Hareton theme runs parallel with the theme of Heathcliff's plan of revenge and his yearning for the dead Catherine, but it also repeats and varies the Catherine-Edgar-Heathcliff theme. Many critics and readers feel that there is "some loss of dynamic" (Davies, 2007, p. 47), "a sudden reduction of scale and style" (Paglia, 1991, p. 456) in the second part of the book. Just like the concluding rondo of Beethoven's Sonata Pathétique, the second half of the novel, together with its happy ending, does not meet the expectations set up by the turbulent passionate story of Catherine and Heathcliff in the first part (Wallace, 1986, p. 46), where the moments of increased tension or climax give way to the relatively calm passages and appassionato outbursts of stormy lyricism, 
only to lead to an even more forceful tension or conflict. We shall take the events described from chapter 9 to chapter 16 of the first half of the novel to demonstrate this constant movement from peace, harmony, and poetry to tension, struggle and violence, and ultimately death. In chapter 9, Catherine delivers her famous speech "Nelly, I am Heathcliff" full of poetry and extraordinary power, followed by Heathcliff's departure in the stormy night. Catherine becomes dangerously ill, but she recovers and marries Edgar. The following three years are the period of (apparent) peace that is again disturbed by Heathcliff's return restoring to the story its sinister energy. A slow, emotionally intense crescendo transforms the consonance of Catherine's and Edgar's simple and happy life into a dissonance of a fierce argument between Edgar, Heathcliff and Catherine, with devastating consequences. The conflict culminates in an overwhelming cacophony of "a thousand smiths' hammers beating in [Catherine's] head!" (Brontë, 1983, p. 155), after which she becomes seriously ill and eventually dies in childbirth. With Catherine's death, and later on Isabella's and Edgar's, the new cycle, the new movement, starts with the same, yet slightly different theme that is developed through the story of the second generation, but with less dramatic and violent clashes.

The form of Sand's Mauprat can be compared to the four-movement scheme (allegro-adagioscherzo-finale) of a symphony or a sonata. The short prelude slowly introduces the story and presents the main theme of the novel, the transformation of the narrator/main character Bernard from "a wolf into a man" (Sand, 1997, p. 7) with the help of a beloved woman. This is followed by the description of la Roche-Mauprat castle and Bernard's childhood years marked with violence and cruelty. Soon the second, contrasting theme is introduced in a different, brighter and lyrical key with the character of Patience, a rustic philosopher, a visionary pursuing a utopian dream of a better world based on justice and equality of all men.

During the first hunting episode that takes place in the vicinity and later on at la Roche-Mauprat, Bernard and Edmée meet for the first time. Their love/erotic and metaphysical duel that starts on that stormy night will continue after their arrival at Sainte-Sévère and will go on throughout the novel reaching the climax with the trial of Bernard and his acquittal at the end of the story. The theme of love interweaves with the already announced theme of the long and exhaustive process of Bernard's education, the purpose of which is to turn a wild child into a civilized person. We follow the tumultuous relationship between young lovers, where the periods of the emotional storm are punctuated by the temporary and deceptive moments of calm marked with the hero's silent yearning for Edmée. These passages of the adagio lyrical atmosphere are interrupted with Bernard's appassionato violent outbursts, reflections of his tormented soul.

Their arrival in Paris marks the second part of the story set in a slightly more moderate andante or adagio tempo. Yet, towards the end of the section, there is another violent argument between Edmée and Bernard triggered off by his jealousy and conviction that Edmée does not love him but her "insipid" fiancé M. de La Marche. Bernard decides to leave for America in order to join La Fayette's troops. In spite of the war in the background of this part of the narrative, these two chapters, a kind of scherzo, are dominated by optimism, serenity and lyrical descriptions of 
nature. Bernard recounts his six years of American adventure spent as a soldier, his friendship with Arthur, a doctor and a passionate botanist, and the unexpected arrival of Marcasse. The fourth, final part brings us back to France, to Sainte-Sévère. The relationship between two young lovers is again full of restrained tension. Bernard is continually struggling to subdue his violent instincts and desire to possess Edmée, who in her turn refuses to marry him trying to maintain her independence. With a gradual crescendo and a rising tension, the second hunting episode starts. It presents the repetitions and variations found in the first one, i.e. the gathering of all characters, the main hero and heroine losing their way in the woods and finding themselves near the Gazeau Tower. While in the first episode Bernard gets injured, now it is Edmée who is shot and Bernard is accused of attempted murder.

The climax of the finale is the trial during which the real culprit is discovered. It is Antoine de Mauprat, Bernard's uncle, and Bernard is set free. These powerful dramatic events are followed by the quietening of tone with lyrical punctuations full of cheerfulness and peaceful hope for a better future. Bernard and Edmée with their extended family travel to Switzerland where, in the midst of the beauty of the Alpine landscape, the lovers start their happy life together that will last until Edmée's death many years later.

\section{Dual narration and multiple narrative voices}

E. Brontë and G. Sand frame their narratives in terms of a dual narration. As with the structure of the novels with their "nesting narrative frames" (Paglia, 1991, p. 449), i.e. stories within stories, there is a similar technique used by both authors when it comes to narrators. Nelly Dean's narrative is incorporated in Lockwood's story that is actually a diary. Bernard tells the story of his life to a young man who puts that gloomy tale in a letter addressed to a friend. Their narratives in turn contain other characters' personal histories such as for example Heathcliff's (in chapters 6 and 29), Isabella's (in chapters 13 and 17) in Brontë's novel, or the story of Patience's "philosophical life" (chapter 3) and that of the Mauprats (chapters 1 and 2) in Sand's book.

In Wuthering Heights these personal narratives are always presented in the words of the participants, thus creating a polyphony of voices that enables readers to get multiple views and perspectives of the characters and the events narrated. Nelly is like "a conductor" who sets the tempo of the story, ensures the instruments' (voices') correct entry and in interpreting the score (the events) "subordinates her own personal morality to the overall orchestration" (Williams, 2008, p. 88).

In Sand's Mauprat there is a kind of homophony, rather than polyphony, with Bernard's voice dominating over other characters' voices, superscribing their narratives with his own, since it is mostly through his eyes and filtered through his account that we see people and the events, even when he relays other characters' words and dialogues. 
Even though both narratives belong to the written medium, after just a few passages, absorbed by the story and the voices of the narrators, we forget we are reading a diary and a letter. Soon Lockwood's voice is silenced, as well as that of the young man, with Nelly and Bernard taking up the tale. There are several occasions when in the course of the novels their narratives are interrupted to remind us of the first narrators' presence. With the predominance of the voice and the oral account, both stories preserve the fluidity of the spoken word characteristic of a tale or a ballad.

The principle of contrast present in the novels' structure is further developed in the authors' choice of primary and secondary narrators. Besides the polarity male-female (Lockwood-Nelly Dean), or female-man (unnamed young man is actually George Sand herself in her familiar male guise $^{3}$ - Bernard), they also represent the opposition between the young and the old, between two different ways of living, the country, provincial life and the urban life, as well as between different social classes, young gentlemen from the city, a servant and an old aristocrat. Nelly and Bernard are not only dominant narrative voices, but they also play their part (smaller or bigger) in the events they describe. Different from Lockwood and Sand's young man who are detached listeners/observers, Nelly and Bernard make an integral part of the emotional texture of their accounts as they relive the dramatic stories they unfold.

\section{Themes and motifs}

As with the structure and narrators, the principle of dualism is reflected in the novels' primary and secondary themes as well as in some recurring motifs. The love story is central to both Wuthering Heights and Mauprat. Besides romantic love that seeks to find its fulfilment in the transcendental, the novels explore also other kinds of love, such as sibling/vaguely incestuous, maternal/parental, social love, but also their opposites - the denial or the loss of love, hatred, violence, suffering (mental and physical). Powerful, uncontrollable emotions of love, but also of fury, agony and pain mark the sibling/incestuous relationship between Catherine and Heathcliff, and Edmée and Bernard, as opposed to Cathy's and Hareton's love that is more moderate, tender and restrained. Edmée is to Bernard, what Catherine is to Heathcliff, or Cathy to Hareton. They are non-identical doubles, a body and a soul, two parts of the same being, two halves of "a sundered whole" (Sedgwick in Nelson, 2009, p. 96) that only when they are together can achieve a harmonious state of oneness.

Mauprat and Wuthering Heights in particular, are "a landscape of childhood grief and loss" (Davies, 2007, p. 88). The repetition of the motifs of motherless/orphaned children, of death and

\footnotetext{
${ }^{3}$ For the similarity between the young man/narrator in Mauprat and the character of a young man in Sand's Letters of a Traveller see for example M. Hecquet (1990). Lecture de Mauprat de George Sand. Lille: Presses Universitaires and G. Schaeffer. (1980). 'Nature' chez George Sand: une lecture de "Mauprat”. Romantisme, 10 (30), pp. 5-12.
} 
birth throughout the stories, gives both novels a tragic tone that is only partly balanced with another motif, the motif of a harmonious father-daughter relationship filled with love and devotion that characterizes Edgar's and Cathy's, and Edmée's and her father's idealized life in the isolated worlds of the Grange and Sainte-Sévère.

Another major theme that runs through both novels is the dichotomy between nature and culture represented by two opposing houses Wuthering Heights and Thrushcross Grange, la RocheMauprat and Sainte-Sévère. The great contrast, the tension between the two polarizing estates, is displayed in a wide range of high and low registers emphasized not only by their geographical position, but by their social and emotional differences as well.

While the Heights and la Roche-Mauprat with their barbaric inhabitants are hostile, wild, sinister places exposed to the elements of nature, the Grange and Sainte-Sévère are a feminized world of civilized comfort and luxury situated in a valley and enclosed by a park. The stormy, daemonic energies associated with the fortress-like Heights or the gloomy castle of la Roche-Mauprat and their unreclaimed dwellers are prevalently presented in dynamic, dark timbre rarely interrupted by short interludes of uneasy calm and light. The contained, graceful and static worlds of the Grange and Sainte-Sévère are introduced and developed in bright and joyful tones as the contrasting counter statement.

The motif of books, reading and education is closely linked with these two opposed houses. From Catherine's selected library at the Heights, and Heathcliff being denied instruction by Hindley to Cathy and Edmée's teaching their savage, uncultivated cousins Hareton and Bernard to read and to become civilized, the motif is repeated and developed throughout the novels. The passage from the Heights to the Grange, from la Roche-Mauprat to Sainte-Sévère, from nature to culture, is mirrored and varied through the destinies of their inhabitants and a series of similar or opposing situations and events with different outcomes, mostly in tragic and rarely in humorous tones.

The motifs of freedom and confinement, reason and madness, exposure and enclosure, are inseparable from the two contrasting spheres of the Heights and the Grange, la Roche-Mauprat and Sainte-Sévère and their main protagonists. In particular Catherine and Bernard experience the passage from nature to culture as the loss of freedom, physical and mental. For these two creatures of passionate extremes, the confined spaces of the Grange and Sainte-Sévère cause serious illness, brain-fever. Their dreams and ravings, Catherine's in chapters 9 and 12, and Bernard's in chapter 11, full of contradictory and overwhelming emotions run in a high register reflecting their inner state of mind, their internal drama. Though traumatized, Bernard manages to recover and to reconcile his wild, animal nature with his desire to please Edmée and become educated and civilized, while Catherine's choice of culture (Edgar) over nature (Heathcliff) inevitably leads her towards a violent and tragic close. But the spirit and the image of the dead Catherine is going to resonate throughout the whole novel. Not only does Heathcliff in her daughter and Hareton see "a daguerreotype, (...) reproduction of a lost original" (Davies, 2007, p. 114 ), but Catherine's loss provokes in his mind an endless multiplicity of her images mirrored on 
the surface of every single thing that surrounds him, from the floor to the trees and sky and the air he breathes.

In Brontë's novel, the same motif of passage from one house to another returns two more times but with a variation. First Edgar's sister Isabella, and many years later his daughter Cathy will leave the Grange for the Heights. The passage will prove nearly fatal for both of them since they will live a miserable existence as Heathcliff's prisoners.

The oral quality of the novels that closely links them with the tradition of storytelling typical of folk tales and ballads was already mentioned earlier in the discussion. Folk ballads and legends also appear in the novels in different ways. They are either only mentioned or are incorporated in the text itself. Sand's young narrator speaks of Bluebeard, of the age-old legends of the Ogre and the Bogyman associating them in his terrifying dreams with the evil reputation of the Mauprat family (Sand, 1997, pp. 5-6).

In E. Brontë's Wuthering Heights, Cathy mentions Chevy Chase ballad (1983, p. 332) when mocking Hareton and his poor reading. Towards the end of the novel, Nelly Dean sings "Fairy Annie's Wedding", "a bonny tune" as she describes it (p. 339). Its cheerfulness and light, airy tone are in line with the overall changed atmosphere at the Heights, and Cathy's and Hareton's impending marriage. "The Ghaists Warning", an old Danish ballad, also sung by Nelly, this time to the baby Hareton in the first part of the novel, is set in a completely different mood. It is a grim lullaby of deep, dark and grave tones reintroducing the motif of a dead mother and orphaned children. With its fatal inevitability, the ballad becomes prophetic of Hareton's dismal destiny, as well as that of Linton and Cathy.

Wuthering Heights and Mauprat incorporate in their narratives some other features commonly attributed to both Romantic music and (regional) folk literature/songs such as the focus on the ghostly, the supernatural, the fantastic, the nocturnal, the terrifying.

Besides Bernard's calling his beloved Edmée "a fairy" (Sand, 1997, p. 7), and Cathy being called "a beneficent fairy" by Lockwood and ironically "a good fairy" by Heathcliff (Brontë, 1983, pp. 55, 56), there are certain traits of characters (their physical and internal transformations for example), the theme of nature/culture conflict, the presence of a number of archetypal elements together with the narratives' basic diegetic structure that have induced some critics to compare the novels with fairy tales (Gilbert and Gubar, 1984, pp. 269, 303, Dana, 1997). When we speak of blending the real with the supernatural, we should also mention Gothic fiction that both novels largely draw upon in their use of atmosphere of mystery, suspense, horror and death combined with romance, all typical of this literary genre.

\section{Poetic language}

The connection between music and words is commonly analysed in relation to the musical quality of poetry. But prose fiction can also share with poetry some stylistic devices such as figurative 
language, imagery, or a particular rhythm, all with the purpose of creating a particular mood, emotion or image in the reader's mind. G. Sand's and E. Brontë's prose fiction has often been described as poetic, actually representing the blending of poetic, lyrical, dramatic passages with terse descriptions. In the final part of the exposition, we shall demonstrate how the principle of dualism, the contrasting tones and moods, dynamic shifts are reflected at the narratives' microlevel, i.e. at the level of the sentences, choice of words and in the use of figurative language. Shakespeare, Milton, together with German, English and French Romantic poets have influenced the music of Brontë's and Sand's own language that bears affinities with their great predecessors by assimilation rather than imitation.

One of the things that most readers find striking and memorable are moments of communion of two lovers, as for example the last encounter between Catherine and Heathcliff (chapter 15), or love duels of Edmée and Bernard (chapter 13) that resemble opera duets. They start in the pianissimo dynamic marking, with the lovers' voices abruptly engaging in complex contradictory emotions. Passionate ferocity and eruptions of uncontrollable, profound feelings with dramatic beats of despair create dissonant chords without settling into the union of the final note.

Together with great speeches pronounced by the novels' two main heroines, these "duets" represent the novels' most emotionally gripping scenes. In particular, some critics have compared Catherine's speeches with Jacobean poetic drama, or arias in opera, earthed in recitative (Davies, 2007, p. 47). Edmée's moving confession to the Abbé of her contradictory feelings towards Bernard and her fiancé M. de La Marche is very similar to Catherine's declaration to Nelly on the different nature of love she feels for Edgar and Heathcliff. Both Bernard and Heathcliff, unobserved and silent, overhear the first part of these revelations, and leave convinced they are unloved and disdained.

I've never loved M. de La Marche; I only feel friendship for him. But for Bernard, it's a different feeling, a feeling so strong, so variable, so full of excitement, of hatred, of fear, of pity, of anger, and of tenderness, that I can't understand it at all, (...). Bernard is a savage, a boor (...), an animal who can barely sign his name. (...) But whether he forces me to kill myself or to become a nun, whether he remains as he is or becomes worse, it will be none the less true that I love him. (...) I think only of him, I see only him, (...). When he says he loves me, I see and feel that it's true. That both shocks and delights me. M. de La Marche seems to me insipid and affected since l've known Bernard. Only Bernard seems to me as proud, as irascible, as bold as me, and as weak as me, for he cries like a child when I annoy him, and here am I crying too as I think of him. (Sand, 1997, p. 293)

... he [Heathcliff] shall, never know how I love him; and that, not because he's handsome, Nelly, but because he's more myself than I am. Whatever our souls are made of, his and mine are the same, and Linton's is as different as a moonbeam from lightning, or frost from fire. (...) 
My love for Linton is like the foliage in the woods. Time will change it, I'm well aware, as winter changes the trees. My love for Heathcliff resembles the eternal rocks beneath - a source of little visible delight, but necessary. Nelly, I am Heathcliff - he's always, always in my mind -- not as a pleasure, any more than I am always a pleasure to myself - but as my own being, (...).

(Brontë, 1983, pp. 121, 122)

Edmée expresses her feelings using gradation, metaphors and a series of contrasting emotions of love and hate, fear and pity, anger and tenderness, audacity and weakness. Catherine highlights the difference between Heathcliff and Edgar employing simile and antithetical pairs of nature imagery of frost/fire, moonbeam/ lightning, deciduous trees/eternal rocks conveying through this symbolic language the ideas of a passing love against eternal love, of time against eternity, of the conscious against the unconscious, in an attempt to reconcile contraries and conflicts of her own nature while hoping to achieve unity. The repetitions, the antithesis in a crescendo tone in both speeches, create analogies that lead to an identification where there is no more division between the self and the other, where two becomes one. This dynamic coexistence and vacillating between the wild and the civilized, good and evil, strong and weak, the self and the other, freedom and confinement, light and dark, life and death, also represent the novels" hermeneutic code that needs to be decoded like a piece of music needs.

Edmée's confession has all the vehemence and passion of Catherine's speech, and it conveys the same feeling of oneness, of the unbreakable bond and destiny that links Edmée with her alter ego Bernard, and as it links Catherine with Heathcliff, but it lacks its power and poetic beauty.

The passages quoted give a glimpse of the abundance of metaphors, simile and other literary devices that render Brontë's and Sand's prose poetic and musical. The same quality can be observed in many descriptive passages of the novels.

The full moon shed floods of its calm light upon the ploughed fields. The jaded plants straightened up their stems, every leaf seemed to breathe in through all its pores the moist coolness of the night. (...) A little meadow marguerite seemed to me so beautiful, with its golden calyx filled with diamonds of dew, that I picked it and covered it with kisses, crying, in a kind of delightful delirium: "It's you Edmée! Yes, it's you! You're here! You no longer shun me!" (Sand, 1997, pp.104, 105)

This extract from Sand's Mauprat describes Bernard's wandering into an open field and the pleasure he experiences in the countryside lit up by the moon and the feeling of "the voluptuous beauty and sublime manifestation of the night" (Sand, 1997, p. 104). For the first time, a close contact with nature for the hero does not mean yielding to his low, animal instincts, as it was the case earlier, but it marks the beginning of his transformation. Bernard sees both the flower and the girl as God's creations, and the whole landscape appears to him like "an earthly reflection of heaven's scattered light" (Hecquet, 1990, p. 115). The atmosphere of lightness, fluidity, is achieved with the rhythmic flow of words and the expressions such as "floods of light", "leaf 
seemed to breathe", "moist coolness of the night", "Edmée's image floated before me", "velvety outlines of gentle hills seemed to play in the pure light of the moon", while the musicality and lyricism are intensified with the pair-bonded alliterations, "meadow marguerite", "diamonds of dew", "delightful delirium", "covered it with kisses."

I lingered round them, under that benign sky; watched the moths fluttering among the heath, and hare-bells; listened to the soft wind breathing through the grass; and wondered how anyone could ever imagine unquiet slumbers, for the sleepers in that quiet earth. (Brontë, 1983, p. 367)

The rhythm, punctuation, alliterations, "heath and hare-bells", "slumbers, sleepers", the alternating 'I' and ' $w$ ' alliterations, in "lingered, listened, watched, wondered", and near-chiasmus in "unquiet slumbers, sleepers in quiet earth", (Davies, 2007, p. 93) together with the writer's favourite words, "heath", "wind", "earth" render the passage full of (symbolic) music. "Heath" evokes Heathcliff, "earth" Catherine and "hare-bells" Hareton, Isabelle and Ellen. The soft wind does not blow, but it breathes through the grass like a living thing. Quiet earth is the "source, grounding and destination" (Davies, 1994, p. 173) that assimilates the graves and head-stones of Catherine, Edgar and Heathcliff, it is the mother that takes back home the bodies of her children. The heath as a symbol of spiritual purity, romantic love, and a moth, a synonym of soul, death, but also of resurrection and salvation (Impelluso, 2003), can be interpreted as the allusion to a new life, "an eternal empire of happiness and Glory" for Catherine and Heathcliff in their heaven on the moor and "in that quiet earth" (Brontë, 1996, p. 178; 1983, p. 367).

Lockwood's "lyrical meditation" seems to restore calm and establish balance of the contradictions running from the very first pages of the book, bringing "the story to an andante pianissimo conclusion" (Davies, 2007, p. 94) compared by some critics with the second movement of Beethoven's Sonata Opus 111 (Davies, 2007, p. 52, Wallace,1986, pp. 136-144).

The relation between words and music in Wuthering Heights and Mauprat exists on multiple levels, from their literary origins in the oral tradition and folklore, the overall structure of a symphony or sonata with polyphony/homophony of narrative voices, primary and secondary themes, recurring motifs, lyrical and dramatic passages to poetic imagery, language and rhythm of their prose. This "covert musical presence" (Wolf, 1997, p. 44), discernible in the use of musical structures and techniques, has offered the possibility to interpret E. Brontë and G. Sand's novels in the context of intermedial studies, more precisely in the field of "word and music studies" (Wolf, 1997, p. 37), as we have done in this paper.

Like a musical score, Wuthering Heights and Mauprat with their complex narrative structures and texture exist as a unique piece of art, offering at the same time numerous possibilities of interpretations that have given rise to a plethora of readings, from structuralist, Marxist, psychoanalytic to feminist, and, of course, musical.

E. M. Forster, discussing novels and the rhythm of prose, tried (unsuccessfully) to find a different kind of resemblance between music and a work of literature. He was wondering whether it was 
possible to experience an effect comparable to the effect of listening to, for example, a Beethoven's Fifth Symphony. When the orchestra stops we hear something that has never been actually played and all the parts of the composition enter our mind at once and extend one another into a common entity (1966, p. 169). Although Forster found no analogy, it seems that there are prose works that can offer such an overwhelming emotion. Hennessy speaks of synaesthesia suggesting that Brontë's musicality might have subconsciously influenced her creative writing (2018, p. 96). We believe that the same can be said of G. Sand and that these two women writers have created the kind of fiction E. M. Forster was looking for. Because, long after we put the books down, the music of their prose resonates in our minds as our thoughts keep going back to Edmée and Bernard, Catherine and Heathcliff, and to the profound philosophical questions raised by their stories.

\section{References}

Brontë, E. (1983). Wuthering Heights. Harmondsworth: Penguin Books.

Sand, G. (1997). Mauprat. Oxford: Oxford University Press.

Bara, O. (2006). "J'avais presque oublié que j'étais née musicienne aussi... ": musique et identité dans "Histoire de ma vie". In: S. Bernard-Griffiths and J.-L. Diaz, eds., Lire "Histoire de ma vie" de George Sand. Clermont-Ferrand: Presses universitaires Blaise-Pascal, pp. 143-160.

Barker, J. (2007). The Haworth context. In: H. Glen, ed., The Cambridge Companion to the Brontës, 4th ed. Cambridge: Cambridge University Press, pp. 13-33.

Brontë E. (1996). Butterfly. In: S. Lonoff, ed., The Belgian Essays. New Haven \& London: Yale University Press, pp. 176-192.

Dana, C. (1997). De Corambé à Mauprat: La naissance d'un roman de George Sand. George Sand Studies, 16 (1-2), pp. 29-39.

Davies, S. (1994). Emily Brontë: Heretic. London: The Women's Press.

Davies, S. (2007). Emily Brontë. Tavistock: Northcote House Publishers.

Donoghue, D. (1970). The Other Emily. In: I. Gregor, ed., The Brontës, A Collection of Critical Essays. Englewood Cliffs, New Jersey: Prentice-Hall, Inc., pp. 157-172.

Forster, E. M. (1966). Aspects of the Novel. London: Penguin Books. 
Gilbert, S. M. and Gubar, S. (1984). Looking Oppositely: Emily Brontë's Bible of Hell. In: The Madwoman in the Attic, The Woman Writer and the Nineteenth-Century Literary Imagination. New Haven and London: Yale University Press, pp. 248-308.

Goodridge, J. F. (1971). Emily Brontë's "Wuthering Heights". London: Edward Arnold Publishers.

Hecquet, M. (1990). Lecture de Mauprat de George Sand. Lille: Presses Universitaires.

Hennessy. J. (2018). Emily Jane Brontë and Her Music. York: W K Publishing.

Impelluso, L. (2003). La natura e i suoi simboli: Piante, fiori, animali, Dizionario dell'Arte. Milano: Mondadori Electa.

Mallet, F. (1995). George Sand. Paris: Bernard Grasset.

Marix-Spire, Th. (1954). Les Romantiques et la Musique, Le Cas George Sand, 1804-1838. Paris: Nouvelles Éditions Latines.

Nelson, G. (2009). Vampiric Discourse in Emily Brontë's "Wuthering Heights". Victorian Network,1 (1), pp. 92-101.

Paglia, C. (1991). Romantic Shadows: Emily Brontë. Sexual Personae, Art and Decadence from Nefertiti to Emily Dickinson. New York: Vintage Books, pp. 439-459.

Powell, D.A. (2001). While the Music Lasts: The Representation of Music in the Works of George Sand. Lewisburg: Bucknell University Press.

Sand, G. (1966-1991). Correspondance. G. Lubin, ed., Paris: Garnier.

Sand, G. (1991). Story of My Life. Albany: State University Press of New York.

Schaeffer, G. (1980). 'Nature' chez George Sand: une lecture de "Mauprat”. Romantisme, 10 (30), pp. 5-12.

Visick, M. (1967). The Genesis of "Wuthering Heights". 2nd ed. London: Hong Kong University Press, Oxford University Press.

Wallace, R. K. (1986). Emily Brontë and Beethoven: Romantic Equilibrium in Fiction and Music. Athens, London: University of Georgia Press. 
Williams, M. H. (2008). The Hieroglyphics of Catherine: Emily Brontë and the Musical Matrix. In: S. Hagan and J. Wells, eds., The Brontës in the World of the Arts. Aldershot and Burlington: Ashgate, pp. 81100.

Wolf, W. (1997). Musicalized Fiction and Intermediality. Theoretical Aspects of Word and Music Studies. In: Word and Music Studies: Defining the Field, Proceedings of the First International Conference on Word and Music Studies at Graz. Amsterdam: Rodopi, pp. 37-58. 